\title{
KEBIJAKAN TATA RUANG DI KABUPATEN KUTAI KARTANEGARA (STUDI VALORISASI RUANG)
}

\author{
Rahayu Subekti, Lego Karjoko, dan Wida Astuti \\ Fakultas Hukum Universitas Sebelas Maret Surakarta \\ (rahayusubekti@yahoo.co.id), (Ikarjoko63@yahoo.co.id), (widaastuti60@vahoo.co.id)
}

\begin{abstract}
The objective of research was to find out the existing condition of spatial layout the Kutai Kartanegara Regency's Government used and to find out the policy of Kutai Kartanegara Regency's Government in spatial layout. In this research, Empirical research on Law (ELr) was used. ELr seeks to understand and explain how law works in the real world. This study was a descriptive developmental one providing a systematical description on the object to be studied, and then a model was developed to address the problems in the field. The research approach used was qualitative approach. The research was taken place in Kutai Kartanegara regency. From the result of research and discussion, two conclusions could be drawn. Firstly, the existing condition of land use in Kutai Kartanegara regency showed the land use for various activities such as: mining, forestry, gardening, and farming. The shift of land function increased over years. Secondly, the government of Kutai Kartanegara regency had developed draft Local regulation of regency about rT rW or Zoning for Kutai Kartanegara regency, but it had not been proposed to the Local Legislative Assembly's (dprd's) discussion because there had been no provincial regulation about rTrW or Zoning of East Kalimantan province
\end{abstract}

Key words : policy, Special layout, Valorisation

\begin{abstract}
Abstrak
Tujuan penelitian adalah untuk mengetahui existing condition tata ruang yang digunakan Kabupaten Kutai Kartanegara, untuk mengetahui kebijakan Pemerintah Kabupaten Kutai Negara dalam penataan ruang . Dalam penelitian ini digunakan metode Empirical research on Law (ELr). ELr seeks to understand and explain how law works in the real world. Adapun sifat penelitiannya deskriptif developmental yang memberikan gambaran secara sistematis terhadap obyek yang akan diteliti, selanjutnya disusun model yang dapat dikembangkan untuk mengatasi problema di lapangan. Pendekatan penelitian menggunakan pendekatan kualitatif. Lokasi penelitian meliputi Kabupaten Kutai Kartanegara. Dari Hasil penelitian dan pembahasan dihasilkan dua kesimpulan, yaitu : pertama, Kondisi existing Penggunaan tanah di Kabupaten Kutai Kartanegara untuk bermacam - macam kegiatan diantaranya yaitu : . Kegiatan pertambangan , Kegiatan Kehutanan, Kegiatan Perkebunan, kegiatan pertanian. Terjadi pengalihan fungsi lahan yang meningkat dari tahun ketahun Kedua, Pemerintah Kabupaten Kutai Kartanegara telah membuat Draft Rancangan Peraturan Daerah Kabupaten Tentang RTRW maupun Zonasi Kabupaten Kutai Kertanegara, hanya saja belum bisa diajukan dalam pembahasan dengan DPRD karena Peraturan Daerah Propinsi tentang RTRW maupun zonasi Provinsi Kalimantan Timur belum ada.
\end{abstract}

Kata kunci : Kebijakan, tata ruang, valorisasi

\section{A. Pendahuluan}

Tanah merupakan suatu kebutuhan yang mendasar bagi manusia, karena. tanah merupakan tempat manusia untuk hidup. Sejak lahir hingga meninggal, manusia membutuhkan tanah pun termasuk untuk pembangunan. Begitu pentingnya tanah bagi manusia, maka tanah harus dimanfaatkan sebaik dan secermat mungkin. Ironisnya, dari waktu ke waktu jumlah tanah semakin menipis sejalan dengan pertumbuhan penduduk yang semakin meledak. Dalam hal ini, tanah mempunyai dimensi ekonomi, sosial, kultural dan politik (Bernhard Limbong, 2011: 1). Tanah dinilai sebagai suatu harta bersifat tetap yang dicadangkan untuk kehidupan yang akan datang. Dilihat dari faktanya, tanah merupakan sarana tempat tinggal bagi persekutuan hukum dan seluruh anggotanya sekaligus memberikan penghidupan kepada pemiliknya (I Gede A.B. Wiranata, 2005: 244) .

Kebijakan Tata Ruang di Kabupaten .... 
Kekuasaan yang diberikan kepada Negara atas bumi, air dan kekayaan alam yang terkandung di dalamnya itu meletakkan kewajiban kepada Negara untuk sebagai yang dikatakan UndangUndang Pokok Agraria "mengatur pemilikan dan memimpin penggunaannya, hingga semua tanah di seluruh wilayah kedaulatan Bangsa dipergunakan untuk sebesar-besarnya kemakmuran rakyat" (Boedi Harsono, 2003: 173).

Pasal 14 Undang - Undang No.5 tahun 1960 tentang Pokok - Pokok Hukum agraria atau yang dikenal dengan Undang-Undang Pokok Agraria (UUPA) sejak semula telah menggariskan perlunya dibuat rencana umum berkenaan dengan persediaan, peruntukkan, dan penggunaan tanah untuk berbagai keperluan. UUPA memang tidak hanya berorientasi pada pengembangan di bidang pertanian. Untuk itu diperlukan adanya perencanaan peruntukkan dan penggunaan tanah yakni menggunakan tanah sesuai dengan rencana yang telah ditetapkan oleh pemerintah. Sehingga perlu dikembangkan penatagunaan tanah yang disebut juga pola penguasaan, penggunaan dan pemanfaatan tanah secara efisien dan efektif sesuai dengan rencana tata ruang yang telah ditetapkan, pengendalian dan pengawasan harus dapat menjadi alat pemacu secara terarah dan terkendali bagi potensi pengembangan lahan yang dapat memberikan peningkatan keuntungan secara sosial, ekonomi dan fisik (Maria S.W. sumardjono, 2001: 44).

Penataan ruang khususnya kota-kota di Indonesia masih dilihat hanya sebatas untuk memenuhi pertumbuhan pembangunan dan cenderung berorientasi pada upaya untuk mencapai target pertumbuhan ekonomi, atau untuk memenuhi kebutuhan pengembangan suatu kawasan tertentu yang tidak bisa dihindari. Orientasi penataan kota yang demikian itu kurang mempertimbangkan tujuan penataan dan penggunaan ruang yang sesuai dengan peruntukannya (Edy Lisdiyono, 2008: 5).

Pelaksana pembangunan saat ini juga menghadapi tugas yang sangat berat karena kebanyakan daerah di Indonesia tumbuh secara alamiah tanpa berlandaskan tata ruang yang baik. Pertumbuhan penduduk yang melesat secara fenomenal menuntut pewadahan aneka aktivitas dan dalam suatu tata ruang utamanya didaerah perkotaan. Kenyataan menunjukkan bahwa pelaksana atau perencana pembangunan di Indonesia masih belum berhasil secara optimal menjawab tantangan dan berbagai konflik yang terjadi dilapangan. Sebab masalah spasial (ruang) selain berdimensi politik (bagi pemerintah) juga berdimensi sosial ekonomi dan sosial budaya (bagi masyarakat) sehingga tata ruang yang disusun lebih merupakan gambaran ideal saja yang dalam kenyataannya sangat sulit untuk diwujudkan

Tujuan-tujuan serta moda penetapan nilai (valorisasi) ruang dalam bingkai wilayah pengurusan publik yang dilekati kekuatan hukum adalah titik berat persoalan. Krisis kecukupan tanah dalam konteks kelayakan kemanusiaan dari nafkah pertanian pangan, pusat keprihatinan dari generasi legislasi yang melahirkan UU Pokok Agraria (UU No. 5 Tahun 1960) separuh abad yang lampau, bukan saja tidak pernah mengalami pembalikan. Akan tetapi, hal itu telah menjelma menjadi krisis perusakan pulau-pulau yang memotong daur-daur ekologis beserta daur reproduksi social di situ. Skala muka bumi yang mengacu pada kelayakan reproduksi kehidupan nafkah desa / kota kecil $(0,25$ hektar pemilikan tanah sebagai ukuran terkecil) digantikan oleh skala operasi berskala gergasi dari sektor-sektor ekstraktif (100 hektar konsesi atas tanah sebagai ukuran terkecil tanpa batas atas).

Kasus Indonesia menunjukkan valorisasi untuk sepetak permukaan bumi yang sama bisa dilakukan berulang-ulang untuk mempertahankan potensi penciptaan nilai di situ. Wilayah pengurusan public menjadi dan diperlukan sepenuhnya sebagai objek ekonomik. Ruang bermukim menyejarah beralih rupa menjadi ruang-ruang transient kapan pun bisa berganti peruntukannya dan status legalnya.Contoh episode-episode ekstraksi bahan mentah industrial berlapis yang berlangsung sejak akhir abad ke-19 sampai sekarang di wilayah Pulau Kalimantan bagian timur. Episode yang dimaksud adalah perluasan ekstraksi kayu hutan primer disusul dengan perluasan ekstraksi minyak dan gas, kemudian perluasan ekstraksi batu bara' .

Dari contoh tersebut, produksi ruang lewat penentuan wilayah yang dilakukan secara hukum mengingkari proses sosial penggunaan dan penghunian ruang serta proses ekologis di situ. Pengaturan pemanfaatan kawasan ruang di kawasan budi daya seperti eksploitasi pertambangan, budi daya kehutanan, budi daya pertanian, dan kegiatan pembangunan permukiman, industri, pariwisata dan lain-lain yang sejenis, sehingga tercapai tata ruang kawasan budi daya. Dengan demikian, dalam pembentukan penataan ruang atau struktur tata ruang harus ada keserasian antara sumberdaya alam hayati dan nonhayati, sehingga timbul keseimbangan fungsi ruang. Merosotnya kualitas lingkungan salah satunya disebabkan oleh penggunaan ruang yang tidak sesuai dengan kondisi lingkungan dan potensi wilayah. U n t u k mengantisipasi hal tersebut telah diamanatkan 
dalam Ketetapan Majelis Permusyawaratan Rakyat No. IX/MPR/2001 tentang "Pembaruan Agraria dan pengelolaan Sumber daya alam yang secara filosofi disebutkan : " bahwa pengelolaan sumber daya alam yang adil, berkelanjutan, dan ramah lingkungan harus dilakukan dengan cara terkoordinasi, terpadu dan menampung dinamika, aspirasi dan peran serta masyarakat serta menyelesaikan konflik. Kemerosotan lingkungan bisa juga terjadi apabila pemanfaatan ruang dan pemanfaatan sumber daya alam yang ada melebihi kapasitas lingkungan, termasuk terjadinya pengalihan fungsi ruang. Pengalihan fungsi ruang yang demikian itu terjadi juga dalam pengembangan Kutai Kartanegara, di mana kawasan-kawasan yang semestinya dikonservasi justru dialihfungsikan untuk pengembangan kawasan industri, perdagangan, permukiman penduduk dan lain-lain.

Selanjutnya dikatakan Bell and McGillivray "However, with the progress of the society, the central role of the land development process started to change. It became more and more complex in nature due to the intensity of a certain development activity that required determining issues relating to location, size and patterns of land utilisation (Bell, S \& McGillivray, D., 2000). Selanjutnya Ainul Jaria Maidin mengatakan Initially the land development system was very much influenced by engineering and architectural factors to suit the land development problems and meet the demands of creating a healthy living environment for the population (Ainul Jaria Maidin, 2008).

\section{B. Metode penelitian}

1. Jenis dan Sifat Penelitian

Dalam penelitian ini digunakan metode Empirical research on Law (ELr). ELr seeks to understand and explain how law works in the real world (Martin Partington in Cane and Critzer, 2010: 1003). The results of empirical research on law are (or shuld be) central to the concerns of academic analysis of Law (Mccrudden, 2006) as well as more generally to understanding the role of law in modern society (Martin, 2010: 1003). Pendekatan yang digunakan bersifat sosiologis/empiris menggunakan pendekatan non positivistik dan menggunakan analisis bersifat kualitatif (Peter Mahmud, 2006). Adapun sifat penelitiannya deskriptif developmental yang memberikan gambaran secara sistematis terhadap obyek yang akan diteliti, selanjutnya disusun model yang dapat dikembangkan untuk mengatasi problema di lapangan.

\section{Pendekatan Penelitian}

Pendekatan penelitian menggunakan pendekatan penelitian kualitatif. Dengan mengutip pendapat dari Denzin dan Lincoln (Lexy Moleong, 2005: 5) menjelaskan bahwa penelitian kualitatif adalah penelitian yang menggunakan latar alamiah, dengan maksud menafsirkan fenomena yang terjadi dan dilakukan dengan jalan melibatkan berbagai metode yang ada.

\section{Lokasi dan waktu penelitian}

Lokasi penelitian meliputi Kutai Kartanegara Kalimantan Timur.

\section{Jenis dan Sumber data}

Dalam penelitian ini data yang diperlukan meliputi data primer maupun data sekunder. Data Primer, yaitu data yang diperoleh dari sumber data langsung atau tangan pertama, terutama yang menyangkut aspek perilaku, persepsi, sikap, dan motivasi eksekutif dalam membuat kebijakan. Data Sekunder, yaitu data yang bukan diusahakan sendiri pengumpulannya oleh peneliti (Marzuki, 2002: 56). Data sekunder dapat berupa majalah, laporan, hasil penelitian terdahulu, peraturan perundang-undangan serta publikasi lainnya. Sumber data sekunder meliputi bahan hukum primer, sekunder dan tersier.

\section{Instrumen Pengumpul data}

Instumen pengumpul data terbagi menjadi dua yakni untuk data primer menggunakan wawancara dan kuesioner. Wawancara ini dilakukan dengan indeepht interview, yaitu metode pengumpulan data melalui wawancara yang dilakukan secara mendalam kepada sumber data (W.Gulo, 2003: 119). Adapun untuk data sekunder menggunakan Identifikasi isi dengan metode studi kepustakaan.

\section{Analisis data}

Dalam penelitian ini penulis menggunakan teknik analisis kualitatif, mengingat data yang terkumpul sebagian besar merupakan data kualitatif.

\section{Hasil Penelitian dan Pembahasan}

1. Kondisi Existing Penggunaan Tanah di Kabupaten Kutai Kartanegara

Salah satu segi pembangunan nasional adalah berkaitan dengan kebijaksanaan pertanahan. Masalah pertanahan adalah masalah yang terkait langsung dengan rakyat,

Kebijakan Tata Ruang di Kabupaten .... 
sebab tanah merupakan kebutuhan dasar (basic need) masyarakat secara keseluruhan. Karena itu diperlukan penanganan dan pengaturan yang ekstra hati-hati dan seksama. Keterpaduan pendekatan yang bersifat konseptual mutlak diperlukan karena tanah atau ruang muka bumi dalam wilayah negara kita luasnya terbatas. Sementara itu , disisi lain perkembangan kegiatan kehidupan dan penghidupan bangsa kita memerlukan tanah yang luas, tidak saja untuk memenuhi kebutuhan penduduk yang dari keberhasilan pembangunan. (Muchsin, Imam Koeswoyo, 2008:13).

Sesuai UUD 1945, Pasal 33 ayat (3) bahwa bumi, air dan kekayaan alam yng terkandung didalamnya adalah karunia Tuhan yang Maha Esa, dikuasai oleh Negara dan dimanfaatkan sebesar-besarnya untuk kemakmuran rakyat. Didalam UUPA selanjutnya dijabarkan bahwa dalam rangka mewujudkan pemanfaatan tanah bagi sebesar-besarnya kemakmuran rakyat, Negara sebagai organisasi kekuasaan bangsa Indonesia diberi wewenang untuk pada tingkatan yang tertinggi :

a. Mengatur dan menyelenggarakan peruntukan, penggunaan, persediaan tanah dan pemeliharaannya;

b. Menentukan dan mengatur hak-hak yang dapat dipunyai hak atas tanah

c. Menentukan dan mengatur hubunganhubungan hukum antara orang-orang dan perbuatan-perbuatan yang mengenai tanah.

Dari uraian diatas makin jelaslah bahwa dalam rangka memenuhi kebutuhan pembangunan yang beraneka ragam diperlukan pengembangan pola tata ruang yang menyerasikan tata guna tanah, tata guna air dan tata guna sumber daya alam lainnya dalam satu kesatuan lingkungan yang serasi, dinamis dan bernuansa jangka panjang. ( Hasni, 33)

Tata Ruang sebenarnya memiliki fungsi penting dan menentukan pada tahap pemanfaatan ruang sebagai upaya pengendalian tata ruang wilayah, serta merupakan instrumen bagi upaya antisipasi penurunan kualitas ruang. Walaupun demikian, tidak dapat disangkal bahwa kebijakan tata ruang tersebut terkadang menimbulkan benturan antara pendekatanpendekatan teknokratik dan komersial di satu sisi dan pendekatan humanis di sisi yang lain.

Demikian juga dengan penggunaan tanah di Kabupaten Kutai Kartanegara. Berikut adalah kondisi existing penggunaan tanah di Kabupaten Kutai Kartanegara :

1. Penggunaan Lahan

Penggunaan lahan di Kabupaten Kutai Kartanegara berdasarkan PJU Kabupaten Kutai Kartanegara tahun 2008 dapat dikelompokkan kedalam 3 kelompok besar, yaitu penggunaan lahan untuk perhutanan, rawa, pertanian dan non pertanian.

2. Perkebunan

Pada tahun 2010, luas perkebunan rakyat di Kutai Kartanegara menurut jenisnya adalah 44.747 ha .Untuk tanaman yang paling banyak adalah Karet (14.218), kemudian kelapa sawit (9.665) dan paling sedikit adalah cengkeh dan kemiri( 5) untuk lebih detailnya dapat dilihat pada tabel 1 dibawah ini :

\section{Tabel 1}

\section{LUAS AREAL dAN PROdUKSI TANAMAN PERKEBUNAN RAKYAT MENURUT JENISNYA}

\begin{tabular}{|c|c|c|c|c|c|}
\hline \multirow{2}{*}{$\begin{array}{c}\text { JENIS TANAMAN } \\
\text { Crops }\end{array}$} & \multicolumn{4}{|c|}{ LUAS AREAL (Ha) - Planted Area } & \multirow{2}{*}{$\begin{array}{c}\text { Jumlah } \\
\text { Total }\end{array}$} \\
\hline & TB & TBM & TM & TT/TR & \\
\hline [1] & [2] & [3] & [4] & [5] & [6] \\
\hline 1. Kelapa / Coconut & - & 4346 & 4166 & 1090 & 9602 \\
\hline Kelapa Sawit/ Oil Palm & - & 480 & 7853 & 1332 & 9665 \\
\hline Karet / Rubber & - & 8719 & 5253 & 246 & 14218 \\
\hline Lada / Pepper & - & 348 & 1321 & 688 & 2357 \\
\hline Kakao / Cocoa & - & 183 & 356 & 219 & 758 \\
\hline Kopi / Coffee & - & 1 & 9 & 4 & 14 \\
\hline Aren / Sugar Palm & - & 1188 & 5347 & 625 & 7160 \\
\hline Kapuk / Kapok & - & - & - & - & - \\
\hline Cengkeh / Clove & - & 1 & 2 & 2 & 5 \\
\hline 10. Panili / vanilla & - & - & - & - & - \\
\hline
\end{tabular}




\begin{tabular}{|c|c|c|c|c|c|c|c|}
\hline 11. & \multicolumn{2}{|c|}{ Kayu Manis / Cassiavera } & - & - & - & - & - \\
\hline 12. & \multicolumn{2}{|c|}{ Kemiri / Candlenut } & - & 1 & 2 & 2 & 5 \\
\hline 13. & \multicolumn{2}{|c|}{ Pala / Nutmeg } & |- & 203 & 168 & 63 & 434 \\
\hline 14. & \multicolumn{2}{|c|}{ J. Mete / Cashew } & - & - & - & - & - \\
\hline 15. & \multicolumn{2}{|c|}{ Pinang/ Arecanut } & - & 154 & 173 & 8 & 335 \\
\hline 16. & \multicolumn{2}{|c|}{ Jarak Pagar } & - & 1 & 11 & 182 & 194 \\
\hline \multirow{2}{*}{\multicolumn{2}{|c|}{ JUMLAH / Total }} & 2010 & - & 15625 & 24661 & 4461 & 44747 \\
\hline & & 2009 & - & 15219 & 21363 & 15713 & 52295 \\
\hline
\end{tabular}

Sumber : Kutai Kartanegara dalam Angka 2011

3. Kehutanan

Pada tahun 2010, luas hutan menurut tata guna hutan kesepakatan sebesar 1.556.439 ha. Ini terbagi menjadi Kawasan Budidaya Kehutanan (KBK) dan Kawasan Hutan Non Budidaya Kehutanan (KBNK). KBK dibagi menjadi
5 macam yaitu hutan lindung $(212.614$ $\mathrm{Ha})$, hutan suaka alam dan wisata (500 $\mathrm{Ha}$ ), hutan taman nasional (50.726 ha), hutan produksi terbatas $(504.924 \mathrm{Ha})$, dan hutan produksi tetap $(787.675 \mathrm{Ha})$. Untuk lebih lanjut dapat dilihat dalam tabel 2 dibawah ini

Tabel 2

Luas Areal Hutan Menurut Tata Guna Hutan Kesepakatan

\begin{tabular}{|c|c|c|c|c|}
\hline & \multirow[b]{2}{*}{ Jenis Hutan } & \multicolumn{3}{|c|}{ Luas (Ha) } \\
\hline & & 2006 & 2007 & 2004 \\
\hline & KAWASAN BUDIDAYA KEHUTANAN (KBK) & 1.647 .622 & 1.647 .622 & - \\
\hline & 1. Hutan lindung/Protection are forest & 231.959 & 231.959 & 231.959 \\
\hline & $\begin{array}{l}\text { 2. Hutan suaka alam dan wisata/Park and } \\
\text { reserve forest }\end{array}$ & 64.907 & 94.907 & 71.268 \\
\hline & $\begin{array}{l}\text { 3. Hutan produksi terbatas/Limited } \\
\text { prodactionforest }\end{array}$ & 61.380 & 61.380 & 539.858 \\
\hline & $\begin{array}{l}\text { 4. Hutan produksi tetap/Devinitive } \\
\text { production forest }\end{array}$ & 507.614 & 507.614 & 788.005 \\
\hline & $\begin{array}{l}\text { 5. Hutan fungsi khusus/Special funcion } \\
\text { forest }\end{array}$ & 781.762 & 781.762 & 64.811 \\
\hline & $\begin{array}{l}\text { KAWASAN HUTAN NON BUDIDAYA } \\
\text { KEHUTANAN (KBNK) }\end{array}$ & 1.073 .009 & 1.073 .009 & 1.073 .009 \\
\hline
\end{tabular}

Sumber data : dinas kehutanan Kab.Kutai Kartanegara

4. Pertanian (Padi)

Perkembangan luas panen padi sawah di Kutai Kartanegara pada tahun 2010 mengalami kenaikan sebesar $3,05 \%$ dan padi ladang mengalami penurunan sebesar $3,39 \%$. Secara riil luas panen padi sawah naik dari 37.514 ha (tahun 2009) menjadi 38.658 ha (tahun 2010). Sedangkan luas panen padi ladang menurun dari 5.220 ha (tahun 2009) menjadi 5.043 ha (tahun 2010).

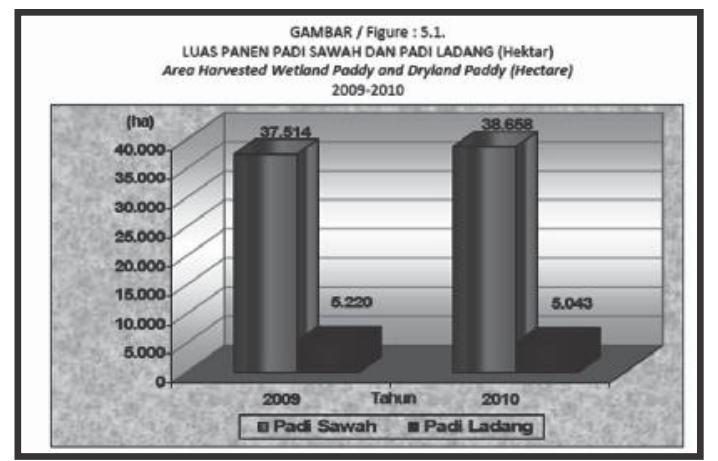

Sumber : Kutai Kartanegara dalam angka 2011

Kebijakan Tata Ruang di Kabupaten .... 
5. Pertambangan

Kegiatan pertambangan $d i$ Kabupaten Kutai Kartanegara mencakup pertambangan migas dan non migas. Dari kegiatan tersebut, minyak bumi dan gas alam merupakan hasil tambang yang sangat besar pengaruhnya dalam perekonomian Kabupaten Kutai Kartanegara khususnya, dan Propinsi Kalimantan Timur pada umumnya, karena hingga kini kedua hasil tambang tersebut merupakan komoditi ekspor utama.

Berdasarkan data dari dinas pertambangan, total produksi batu bara di Kutai Kartanegara tahun 2010 mencapai 29.014.588.384 ton (dari 164 perusahaan tambang batu bara). Hal ini meningkat dari tahun 2009 lalu yang hanya sebesar 20.883 .783 ton (dari 90 perusahaan batu bara)

\section{PROdUKSI BATU BARA (Ton)}

20082010

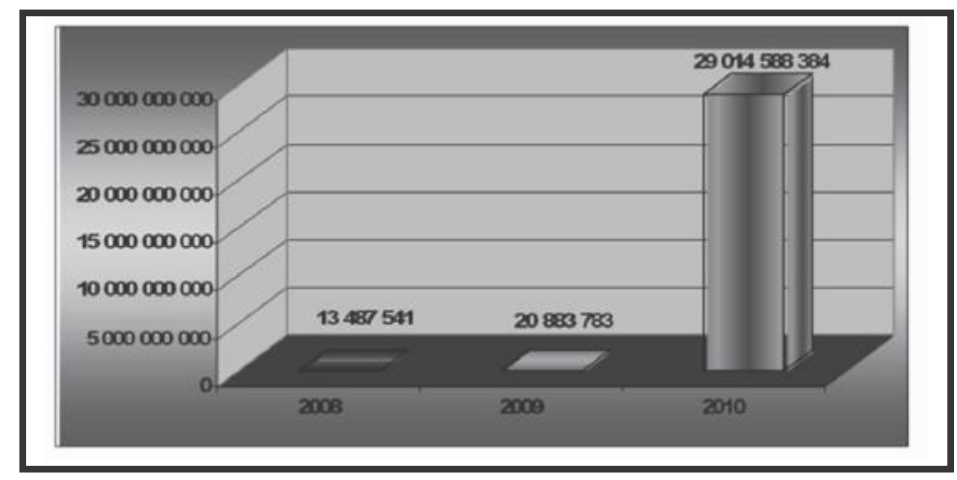

Sumber : Kutai Kartanegara dalam angka 2011

2. Kebijakan Tata Ruang di Kabupaten Kutai Kartanegara

Dalam pemanfaatan tanah harus dilakukan sesuai dengan rencana tata ruang yang ada. Dimana hal tersebut diatur dalam UU no 26 tahun 2007 . Pasal 2 Undang - Undang no. 26 tahun 2007 tentang Penataan ruang menyatakan Dalam kerangka Negara kesatuan republik Indonesia, penataan ruang diselenggarakan berdasarkan asas : Keterpaduan; Keserasian, keselarasan dan keseimbangan ; . Keberlanjutan; Keberdayagunaan dan keberhasilgunaan; Keterbukaan; Kebersamaan dan kemitraan; Kepastian hukum dan keadilan ; Akuntabilitas .

Wewenang pemerintah daerah provinsi dalam penyelenggaraan penataan ruang meliputi :

a. pengaturan pembinaan dan pengawasan terhadap pelaksanaan penataan ruang wilayah provinsi dan kabupaten/kota, serta terhadap pelaksanaan penataan ruang kawasan strategis provinsi dan kabupaten/kota. b. pelaksanaan penataan ruang wilayah provinsi

c. pelaksanaan penataan ruang kawasan strategis propinsi dan

d. kerjasama penataan ruang antar provinsi dan pemvasilitasan kerjasama penataan ruang antar kabupaten/ kota.

Dalam penataan ruang kawasan strategis provinsi , pemerintah daerah melaksanakan :

a. Penetapan kawasan strategis provinsi

b. Perencanaan tata ruang kawasan strategis provinsi

c. Pemanfaatan ruang kawasan strategis provinsi dan

d. Pengendalian pemanfaatan ruang kawasan strategis provinsi.

Dalam rangka penyelenggaraan penataan ruang wilayah provinsi, pemerintah daerah provinsi dapat menyusun petunjuk pelaksanaan bidang penataan ruang pada tingkat provinsi dan Kabupaten / kota, yang dapat dilakukan dengan : 
1) Menyebarluaskan informasi yang berkaitan dengan:

a. rencana umum dan rencana rinci tata ruang dalam rangka pelaksanaan penataan ruang wilayah provinsi

b. arahan peraturan zonasi untuk system provinsi yang disusun dalam rangka pengendalian pemanfaatan ruang wilayah provinsi dan

c. petunjuk pelaksanaan bidang penataan ruang

2) melaksanakan standar pelayanan minimal bidang penataan ruang

Pasal 11 Undang - Undang Penataan Ruang menyatakan wewenang pemerintah daerah kabupaten/ kota dalam penyelenggaraan penataan ruang meliputi :

a. pengaturan, pembinaan dan pengawasan terhadap pelaksanaan penataan ruang wilayah kabupaten /kota dan kawasan strategis kabupaten / kota.

b. pelaksanaan penataan ruang wilayah kabupaten/kota

c. pelaksanaan penataan ruang kawasan strategis kabupaten/kota

d. kerjasama penataan ruang antar kabupaten/kota

Wewenang pemerintah daerah kabupaten/ kota dalam pelaksanaan penataan ruang wilayah kabupaten / kota meliputi :

a. Perencanaan tata ruang wilayah kabupaten / kota

b. Pemanfaatan ruang wilayah kabupaten / kota dan

c. pengendalian pemanfaatan ruang wilayah kabupaten /kota

Adapun penyelenggaraan penataan ruang bertujuan untuk mewujudkan ruang wilayah nasional yang aman nyaman produktif dan berkelanjutan berlandaskan wawasan nusantara dan ketahanan nasional dengan :

a) Terwujudnya keharmonisan antara lingkungan alam dan lingkungan buatan

b) Terwujudnya keterpaduan dalam penggunaan sumber daya alam dan sumber daya buatan dengan memerhatikan sumber daya manusia c) Terwujudnya perlindungan fungsi ruang dan pencegahan dampak negatif lingkungan akibat pemanfaatan ruang. ( Pasal 3 UU no 26 Tahun 2007).

Dalam pengelolaannya Penataan Ruang diklasifikasikan berdasarkan sistem , fungsi, utama kawasan , wilayah administratif, kegiatan kawasan dan nilai strategis kawasan. Penataan ruang berdasarkan sistem terdiri atas sistem wilayah dan sistem sistem internal perkotaan. Penataan ruang berdasarkan fungsi utama kawasan terdiri atas kawasan lindung dan kawasan budidaya . Penataan ruang berdasarkan wilayah administratif terdiri atas penataan ruang wilayah nasional, penataan ruang wilayah propinsi dan penataan ruang wilayah kabupaten / kota. Penataan ruang berdasarkan kegiatan kawasan terdiri atas penataan ruang kawasan perkotaan dan penataan ruang kawasan perdesaan .

Sesuai dengan Pasal 14 Undang Undang No 32 tahun 2004 Urusan wajib yang menjadi kewenangan pemerintahan daerah untuk kabupaten/kota merupakan urusan yang berskala kabupaten/kota diantaranya adalah perencanaan dan pengendalian pembangunan;

Dan perencanaan, pemanfaatan, dan pengawasan tata ruang, maka pemerintah Kabupaten Kutai Kartanegara juga melaksanakan hal tersebut dengan membuat rencana tata ruang wilayah .

Dalam rangka koordinasi penataan ruang daerah (BKPRD) Kabupaten Kutai Kertanegara maka dikeluarkanlah SK Bupati No. 506/ SK-Bup/HK/2011 tentang Pembentukan Badan Koordinasi Penataan Ruang Daerah (BKPRD) Kabupaten Kutai Kertanegara.

1) Perencanaan Tata Ruang, meliputi :

a. Mengkoordinasikan dan merumuskan penyusunan rencana tata ruang Kabupaten

b. Memaduserikan rencana pembangunan jangka panjang dan menengah dengan rencana tata ruang kabupaten serta mempertimbangkan pengarusutamaan pembangunan berkelanjutan melalui instrumen kajian lingkungan hidup strategis.(KLHS). 
c. Mengintegrasikan, memaduserikan dan mengharmonisasikan rencana tata ruang wilayah nasional, rencana tata ruang pulau/kepualauan, rencana tata ruang kawasan strategis nasional, rencana tata ruang wilayah propinsi, rencana tata ruang kawasan strategis Propinsi dan rencana tata ruang wilayah yang berbatasan

d. Mensinergikan penyusunan rencana tata ruang kabupaten dengan propinsi dan antar kabupaten yang berbatasan

e. Mengkoordinasikan pelaksanaan konsultasi Rancangan Peraturan Daerah tentang rencana tata ruang Kabupaten kepada Badan Koordinasi Penataan ruang daerah (BKPRD) Propinsi dan BKPRDN

f. Mengkoordinasikan pelaksanaan evaluasi rencana tata ruang kabupaten ke Propiinsi

g. Mengkoordinasikan proses penetapan rencana tata ruang kabupaten dan

h. mengoptimalkan peran masyarakat dalam perencanaan tata ruang

2). Pemanfaatan ruang meliputi :

a) Mengkoordinasikan penanganan dan penyelesaian permasaIahan dalam pemanfaatan ruang baik di Kabupaten dan memberikan pengarahan serta saran pemecahannya

b) Memberikan rekomendasi guna memecahkan permasalahan dalam pemanfaatan ruang kabupaten

c) Memberikan informasi dan akses kepada pengguna ruang terkait rencana tata ruang kabupaten

d) Menjaga akuntabilitas publik sebagai bentuk layanan pada jajaran pemerintah, swasta dan masyarakat

e) Melakukan fasilitas pelaksanaan kerjasama penataan ruang antar kabupaten

f) Mengoptimalkan peran masyarakat dalam pemanfaatan ruang
3). Pengendalian Pemanfaatan ruang meliputi:

a) Mengkoordinasikan penetapan peraturan zonasi sistem kabupaten

b) Memberikan rekomendasi perizinan pemanfaatan ruang kabupaten

c) Melakukan identifikasi dalam pelaksanaan pelaksanaan insentif dan disinsentif dalam pelaksanaan pemanfaatan ruang kabupaten dengan propinsi dan dengan kabupaten terkait.

d) Melakukan fasilitasi pelaksanaan pemantauan, evaluasi dan pelaporan penyelenggaraan penataan ruang

e) Melakukan fasilitasi pelaksanaan pengendalian pemanfaatan ruang dengan rencana tata ruang

f) Mengoptimalkan peran masyarakat dalam pengendalian pemanfaatan ruang.

Ruang lingkup pengendalian ini terdiri atas ruang lingkup wilayah dan ruang lingkup substansi. Ruang lingkup wilayah meliputi seluruh Kabupaten Kutai Kartanegara, sedangkan ruang lingkup materi meliputi : Zonasi,Aturan insentif dan disinsentif,Aturan perubahan klasifikasi zona ,Perijinan dalam pemanfaatan ruang .pengendalian pemanfaatan ruang melalui pengawasan

Arahan pengaturan zonasi merupakan upaya untuk menghasilkan ketentuan tentang aspek-aspek sebagai berikut : Jenis kegiatan yang diperbolehkan, diperbolehkan dengan syarat, dan dilarang, Intensitas pemanfaatan ruang ,Sarana dan prasarana minimum dan Ketentuanketentuan khusus

Berdasarkan Rencana tata ruang wilayah kabupaten Kutai Kartanegara bagian pengendalian maka disusunlah ketentuan umum peraturan zonasi. Adapun dalam ketentuan tersebut dibagi atas :

A. STRUKTUR RUANG

1. Kawasan perkotaan

2. Kawasan Perdesaan 
3. Kawasan sekitar jaringan jalan dan jembatan

4. Kawasan sekitar jaringan prasarana lalu lintas dan angkutan jalan

5. Kawasan sekitar jaringan pelayanan lalu lintas dan angkutan jalan

6. Kawasan sekitar prasarana transportasi penyebrangan sungai

7. Kawasan sekitar prasarana system jaringan perkereta apian

8. Kawasan sekitar prasarana transportasi udara

9. Kawasan sekitar prasarana system jaringan energy

10. Kawasan sekitar prasarana jaringan telekomunikasi

11. Kawasan sekitar jaringan sumber daya air

12. kawasan sekitar system jaringan persampahan

13. Kawasan sekitar system jaringan air minum

14. kawasan sekitar system jaringan pengelolaan air limbah

15. kawasan sekitar system jaringan drainase

16. kawasan sekitar jaringan jalur dan ruang evakuasi bencana alam

B. Pola Ruang

1. Kawasan hutan lindung

2. kawasan perlindungan setempat

3. Kawasan suaka alam, pelestarian alam dan cagar budaya

4. kawasan rawan bencana alam

5. Kawasan lindung geologi

6. Kawasan peruntukan hutan produksi

7. Kawasan peruntukan pertanian

8. Kawasan peruntukan perikanan

9. kawasan peruntukan pertambangan

10. Kawasan peruntukan Industri

11. Kawasan peruntukan Pariwisata

12. Kawasan peruntukan permukiman

13. Kawasan peruntukan lainnya
C. Kawasan Strategis

1. Kawasan strategis nasional

2. Kawasan strategis Provinsi

3. Kawasan strategis Kabupaten

Berdasarkan Pasal 36 Undang-

Undang No 26 tahun 2007 tentang

Penataan Ruang menyatakan bahwa :

(1) Peraturan zonasi sebagaimana dimaksud dalam Pasal 35 disusun sebagai pedoman pengendalian pemanfaatan ruang.

(2) Peraturan zonasi disusun berdasarkan rencana rinci tata ruang untuk setiap zona pemanfaatan ruang.

(3) Peraturan zonasi ditetapkan dengan:

a. peraturan pemerintah untuk arahan peraturan zonasi sistem nasional;

b. peraturan daerah provinsi untuk arahan peraturan zonasi sistem provinsi; dan

c. peraturan daerah kabupaten/ kota untuk peraturan zonasi.

Demikian juga dengan Pemerintah Kabupaten Kutai Kartanegara, untuk pengendalian ruang juga sudah disusun dalam rencana tata ruang wilayahnya. Untuk peraturan zonasi daerah kabupaten Kutai Kertanegara, sebetulnya sudah dibuat dalam bentuk draft rancangan Perda tentang Rencana tata ruang wilayah / Zonasi , tetapi belum disyahkan sampai sekarang dikarenakan Perda propinsi Kalimantan Timur tentang zonasi belum ada, sehingga perda Zonasi Kabupaten Kutai Kertanegara belum bisa disyahkan .

Dari Pasal 36 Undang - Undang No.26 tahun 2007 tentang penataan ruang yaitu peraturan pemerintah untuk arahan peraturan zonasi sistem nasional dan peraturan daerah provinsi untuk arahan peraturan zonasi sistem propinsi . Jadi sebagai arahan ataupun payung hukum dari perda zonasi, karena mengacu pada perda provinsi maka perda zonasi yang ada dalam draft yang sudah disusun tidak bisa disahkan karena perda yang jadi payung belum ada

Disamping dengan pengaturan zoning,untuk pengendalian juga dilakukan dengan Perizinan. Perizinan 
merupakan salah satu mekanisme pengendalian pemanfaatan ruang menurut UU No. 26 Tahun 2007 mengenai Penataan Ruang. Mekanisme ini merupakan perangkat penting dari pengendalian pemanfaatan ruang, oleh karenanya apabila mekanisme ini terselenggara dengan baik, maka penyimpangan pemanfaatan ruang akan dapat dikurangi, dan secara legal penyimpangan dapat diidentifikasi dan ditertibkan.

Hal tersebut sesuai dengan pendapat dari Safri Nugraha yaitu Perizinan menjadi hal yang penting dalam masyarakat dan kegiatan pemerintahan yaitu :

1) Dalam keadaan bagaimanapun pemerintah harus mengendalikan kehidupan dan perkembangan perekonomian dan kesejahteraan masyarakat, salah satu caranya adalah dengan melakukan pengendalian melalui perijinan

2) Kepentingan negara dan kepentingan pemerintah serta kepentingan masyarakat dalam arti luas tetap harus dijaga keseimbangannya, keseimbangan ketiga kepentingan tersebut harus dijaga dan salah satu cara untuk menjaga keseimbangan tersebut adalah melalui perijinan

3) Perijinan adalah salah satu cara dari wewenang pemerintahan yang dimiliki oleh pemerintah .oleh karena itu penting bagi pemerintah untuk selalu menata kembali perijinan agar tetap sesuai dengan perkembangan perekonomian nasional maupun perekonomian global ..

4) Perizinan juga penting artinya bila ditinjau dari segi dokumentasi. (Safri Nugraha ,2007 :137).

Perizinan merupakan upaya mengatur kegiatan-kegiatan yang memiliki peluang menimbulkan gangguan bagi kepentingan umum. Pada dasarnya prinsip penerapan perizinan dalam pemanfaatan ruang adalah sebagai berikut:

1. Kesehatan individu, keluarga dan komunitas.

2. Pembangunan fisik sesuai hak yang tertata, dilengkapi dengan sirkulasi, akses, keselamatan, dan lain-lain.
3. Kualitas lingkungan yang menjamin kegiatan yang tidak sesuai/ diinginkan (komersial) tidak berlokasi di kawasan tertentu.

Adapun yang dimaksud tindakan pengendalian adalah

1. Membatasi pemanfaatan Iahan dan bangunan, cara pembangunan dilaksanakan, tampilan bangunan, hubungan antar bangunan maupun antara bangunan dengan ruang terbuka.

2. Mengendalikan bentuk fisik (posisi, ukuran, bentuk, jarak, ruang antar bangunan, tutupan lahan dan penanaman) yang disertai dengan tingkat pengendalian terhadap kegiatan atau penggunaan lahan.

Setiap kegiatan dan pembangunan harus memohon izin dari pemerintah setempat yang akan memeriksa kesesuaiannya dengan rencana tata ruang, serta standar teknis, administatif dan legal.

Sesuai dengan Pasal 11 UU No. 26 tahun 2007, maka Pemerintah Kabupaten mempunyai Wewenang utk perencanaan tata ruang wilayah kabupaten/ kota; pemanfaatan ruang wilayah kabupaten/ kota; dan pengendalian pemanfaatan ruang wilayah kabupaten/kota. Dimana dalam pelaksanaan nya dilakukan melalui pemberian izin, pemberian disinsentif Arahan disinsentif pola ruang dalam rangka membatasi pertumbuhan atau mencegah kegiatan yang tidak sejalan dengan rencana tata ruang dan pemberian sanksi. Kebijakan tata ruang yang Dilakukan di Kabupaten Kutai Kartanegara meliputi pemanfaatan ruang yang dilakukan dengan pengaturan Zonasi, yang tercantum dalam rencana tata ruang wilayah nya , yang didalamnya berisi struktur ruang, pola ruang, kawasan strategis. Sesuai dengan Pasal 11 UU No. 26 tahun 2007, maka Pemerintah Kabupaten mempunyai Wewenang utk perencanaan tata ruang wilayah kabupaten/ kota; pemanfaatan ruang wilayah kabupaten/ kota; dan pengendalian pemanfaatan ruang wilayah kabupaten/kota. Dimana dalam pelaksanaannya dilakukan melalui pemberian izin, pemberian disinsentif Arahan disinsentif pola ruang 
dalam rangka membatasi pertumbuhan atau mencegah kegiatan yang tidak sejalan dengan rencana tata ruang dan pemberian sanksi

Sejalan dengan pelaksanaan zonasi maka, pemerintah kabupaten Kutai kertanegara dalam Rencana Tata Ruang Wilayah juga mencantumkannya hanya saja , sesuai dengan UU no 26 tahun 2007 seharusnya peraturan zonasi ditetapkan dengan perda tentang peraturan daerah kabupaten/kota untuk peraturan zonasi.maka pemerintah Kabupaten Kutai Kartanegara masih dalam bentuk draf Raperda, dan draf Raperda sudah jadi bulan maret dan berencana untuk disahkan, tetapi ternyata hal ini terhambat karena Perda propinsi yang dipakai sebagai pedoman dalam pembuatan Perda Kabupaten belum jadi.

\section{d. KESIMPULAN dAN SARAN}

\section{Kesimpulan}

Kondisi existing Penggunaan lahan di Kabupaten Kutai Kartanegara berdasarkan PJU Kabupaten Kutai Kartanegara dapat dikelompokkan kedalam 3 kelompok besar, yaitu penggunaan lahan untuk perhutanan, rawa, pertanian dan non pertanian. Penggunaan lahan di Kutai Kertanegara digunakan untuk bermacam - macam kegiatan diantaranya yaitu : Kegiatan pertambangan yang mencakup pertambangan migas dan non migas, Kehutanan, Perkebunan, Pertanian (Padi, Palawija, dan Hortikultura) dll

Kebijakan Penataan Ruang Yang Dilakukan di Kabupaten Kutai Kartanegara dilakukan berdasarkan Pasal 11 UU No. 26 tahun 2007, yaitu Pemerintah Kabupaten mempunyai Wewenang utk perencanaan tata ruang wilayah kabupaten/ kota; pemanfaatan ruang wilayah kabupaten/ kota; dan pengendalian pemanfaatan ruang wilayah kabupaten/kota, disamping itu juga berdasarkan pada Pasal 14 (huruf b) Undang - Undang No 32 tahun 2004 tentang Pemerintah Daerah maka perencanaan, pemanfaatan, dan pengawasan tata ruang merupakan kewenangan pemerintah daerah kabupaten.

Dalam melaksanakan kewenangan tersebut dituangkan dalam rencana tata ruang wilayah Kabupaten Kutai Kertanegara, yang didalamnya terdapat rencana, pemanfaatan , pengendalian dan juga kawasan strategis. Dimana dalam pengendalian pemanfaatan terdapat ketentuan Umum peraturan zonasi. Hanya saja Kabupaten Kutai Kertanegara belum memiliki Peraturan tentang zonasi, sesuai yang diamanatkan Pasal 36 ayat (3c) UU No. 26 Tahun 2007 bahwa untuk peraturan zonasi daerah Kabupaten ditetapkan dengan peraturan daerah Kabupaten / Kota . Sebetulnya Rancangan/ Draft Raperda Tentang Rencana Tata ruang wilayah/ pengaturan zonasi Kabupaten Kutai Kertanegara sudah ada hanya saja belum bisa disahkan karena Perda tentang rencana tata ruang wilayah/ pengaturan zonasi berdasarkan uu yang baru Provinsi Kalimantan Timur belum ada.

\section{Saran}

Dalam penelitian ini peneliti memberikan saran hendaknya pemerintah propinsi Kalimantan Timur segera membuat Perda tentang Rencana Tata Ruang Wilayah/ pengaturan zonasi berdasarkanUU yang baru sehingga rancangan Perda tentang rencana tata ruang wilayah maupun zonasi kabupaten Kutai Kartanegara dapat segera ditetapkan. 


\section{dAFTAR PUSTAKA}

Ainul Jaria Maidin, 2008. Role of Land Development in Improving Public Health: Way Forward for Malaysia, Journal of the Malaysian Institute of planners, Malaysia.

BPN dan Bappeda Kabupaten Kutai Kertanegara, Kutai Kertanegara dalam Angka 2011.

BAPPEDA Kabupaten Kutai Kertanegara, Rencana Tata Ruang Wilayah Kabupaten Kutai Kertanegara

Basrowi dan Sukidin, 2002, Metode penelitian Kualitatif perspektif Mikro, Surabaya, Insan

Cendikia.

Bernhard Limbong. 2011. pengadaan Tanah Untuk pembangunan. Jakarta: Margaretha Pustaka.

Boedi Harsono. 2003. Hukum Agraria Indonesia, Sejarah pembentukan Undang-Undang pokok Agraria Isi dan pelaksanaannya. Jakarta: Djambatan

Edi Lisdiyono. 2008. "Legislasi Penataan Ruang tentang Pergeseran Kebijakan Hukum Tata Ruang dalam Regulasi Daerah di Kota Semarang". Disertasi Universitas Diponegoro

H. Muchsin dan Imam Koeswoyono. 2008.Aspek Kebijaksanaan Hukum penatagunaan Tanah dan Penataan Ruang.Jakarta.2008

Hasni.Hukum Penataan Ruang dan Penatagunaan Tanah Dalam Konteks UUPA - UUPR- UUPLH. Jakarta.PT RajaGrafindo perkasa

I Gede A.B.Wiranata. 2005. Hukum Adat Indonesia perkembangan dari Masa ke Masa. Bandung: Citra Aditya Bakti

Lawrence M. Friedman, 1997. The Legal System : A Social Science perspective. Russel Sage Foundation : New York.

Lego Karjoko dan I Gusti Ayu, 2010, ...........................Laporan Penelitian Hibah Kerjasama Antar Lembaga dan Perguruan Tinggi, Surakarta, Fakultas hukum UNS.

Lexy J. Moleong. 2005. Metodologi penelitian Kualitatif. Bandung: P.T. Remaja Rosdakarya.

Maria S.W. Sumardjono. 2001. Kebijakan pertanahan Antara regulasi dan Implementasi. Jakarta: Kompas Media Nusantara

Marzuki. 2002. Metodologi riset. Yogyakarta: BPFE-UII.

Peter Mahmud Marzuki. 2006. penelitian Hukum. Akarta: Kencana Prenada Media Group.

Peter M. Blau dan Marshall Meyer. 2000. Birokrasi dalam Masyarakat Modern. (edisi terjemahan Slamet Riyanto). Jakarta: Prestasi Pustakaraya.

Safri Nugraha dkk. 2007. Hukum Adminstrasi Negara.Jakarta. CLGS-FH UI

W. Gulo. 2002. Metodologi penelitian. Jakarta: P.T. Gramedia Widiasarana Indonesia.

website Dinas pengendalian pertanahan daerah kabupaten Sleman

Peraturan Pemerintah Republik Indonesia Nomer 15 Tahun tentang penyelenggaraan Penataan Ruang

Undang - Undang no.32 tahun 2004 tentang Pemerintahan Daerah

Undang - Undang No. 26 Tahun 2007 Tentang Penataan Ruang 